\author{
Stanisław Chrobak* \\ Warszawa
}

\title{
Kultura szkoły katolickiej w kontekście pedagogii salezjanów
}

Termin „kultura” nie jest jednoznaczny. W sensie metaforycznym przeciwstawiana naturze - kultura oznacza pielęgnowanie i uszlachetnianie cielesno-duchowych predyspozycji człowieka. W sensie szerokim (analogicznym, typologicznym i aksjologicznym) kulturą nazywa się całość ludzkich zachowań i działań oraz ich wytworów. Nie istnieje żadna dostatecznie ogólna i powszechnie przyjęta definicja kultury. Formalnie wyróżnia się dwa sposoby rozumienia kultury: dynamiczny - jako działanie, szczególny sposób ludzkiego zachowania i przetwarzającego świat działania oraz statyczny - jako dzieło, wynik materialnej i duchowej działalności człowieka w postaci całokształtu materialnych i duchowych dóbr oraz zdobyczy kulturowych. Faktem bezspornym jest jednak, że kultura ma w życiu człowieka charakter zasadniczy i uniwersalny. Człowiek tworzy kulturę, ale i ona kształtuje jego życie ${ }^{1}$.

* Ks. dr hab. Stanisław Chrobak, prof. UKSW, jest profesorem w Katedrze Historii Wychowania i Dziejów Oświaty, w Wydziale Nauk Pedagogicznych Uniwersytetu Kardynała Stefana Wyszyńskiego w Warszawie. Adres: Wydział Nauk Pedagogicznych UKSW, ul. Wóycickiego 1/3, budynek nr 15, 01-938 Warszawa; e-mail: s.chrobak@uksw.edu.pl.

${ }^{1}$ Andrzej Bronk, „Kultura”, w: Leksykon filozofii klasycznej, red. Józef Herbut (Lublin: Towarzystwo Naukowe KUL, 1997), 332-333. „Każdy człowiek jest włączony w jakąś kulturę, zależy od niej i na nią oddziałuje. Człowiek jest jednocześnie dzieckiem i ojcem kultury, w której żyje. We wszystkie przejawy swego życia wnosi coś, co odróżnia go od reszty stworzenia: nieustanne otwarcie na tajemnicę i nieugaszone pragnienie wiedzy. W konsekwencji każda 
Kultura otwiera perspektywę ludzkiego rozwoju ze względu na prawdę (wiedza), dobro (moralność), piękno (twórczość), boskość (religia). Cywilizacja umożliwia edukację w ramach społeczności zorganizowanej, szerszej niż rodzina i dłużej niż aktualnie żyjące pokolenie. [...] Symbolem miejsca edukacji w kulturze jest szkoła. Już nie tylko rodzice, nie tylko dom, ale całkiem odrębna instytucja, niemająca odpowiednika w świecie zwierząt, przystosowana jest do edukacji ${ }^{2}$.

Każda organizacja wykształca swoją własną kulturę. Kultura łącząca ludzi w organizacji pozostaje w bardzo ścisłym związku z efektywnością organizacji $^{3}$. Badania, których efektem jest niniejszy artykuł, odnoszą się zatem do pytania, jaki kształt powinna przyjąć szkoła, w tym także szkoła katolicka, budując własną kulturę organizacyjna, w której staje się ona cechą stałą szkoły, systemem wzorów zachowań, norm i wartości oraz współżycia i współdziałania, specyficznym dla każdej placówki.

\section{Kultura organizacyjna szkoły}

Szkoła - typ instytucji społecznej i zarazem podstawowa jednostka organizacyjna systemu oświaty, której zadaniem jest kształcenie oraz wychowanie dzieci i młodzieży; budynek będący siedzibą placówki spełniającej cele edukacyjne; wspólnota nauczycieli i uczniów, stanowiąca swoistego rodzaju formę przekazu kulturowego, realizowanego za pośrednictwem wyspecjalizowanych czynności nauczania i uczenia się. Powszechnie wyróżnia się trzy funkcje szkoły:

1) rekonstrukcyjną - polega na odtwarzaniu kultury uniwersalnej i narodowej, przekazaniu uczniom ciagłości procesu historycznego i odtwarzaniu struktury społecznej;

2) adaptacyjną - polega na przystosowaniu uczniów do zastanych struktur życia społeczno-politycznego, wprowadzaniu ich w istnie-

kultura kryje w sobie i wyraża dążenie do jakiejś pełni”. Jan Paweł II, Encyklika Fides et ratio (Poznań: Pallottinum, 1998), 71.

2 Piotr Jaroszyński, „Edukacja na rozdrożu cywilizacji”, w: Filozofia i edukacja, red. Piotr Jaroszyński, Paweł Tarasiewicz, Imelda Chłodna (Lublin: Fundacja „Lubelska Szkoła Filozofii Chrześcijańskiej”, 2005), 13-14.

3 Por. Monika Kostera, Zarzadzanie personelem (Warszawa: Polskie Wydawnictwo Ekonomiczne, 1994), 14-16. 
jące i projektowane role społeczne i zawodowe oraz na takim przedstawianiu obrazu świata, aby uznali oni istniejący ład społeczny za właściwy i słuszny;

3) emancypacyjną - polega na przygotowaniu uczniów do nieprzerwanej aktywności samokształceniowej i samowychowawczej oraz uzdalnianiu ich do krytyki, dzięki czemu mogliby pokonywać istniejące ograniczenia rozwojowe oraz uczestniczyć w przekształcaniu otaczającego ich świata.

Według krytyków, oprócz funkcji założonych, szkoły realizują także funkcje i programy ukryte, które maskują proces powstawania wiedzy oraz fakt podporządkowania przekazu edukacyjnego celom politycznym, ideologicznym i technokratycznym.

Ze względu na organ założycielski i prowadzący wyróżnia się szkoły publiczne (zakładane, prowadzone i utrzymywane przez Ministerstwo Edukacji Narodowej, inne organy administracji państwowej, gminy czy związki komunalne) oraz szkoły niepubliczne (zakładane i prowadzone przez osoby prawne lub fizyczne), pozbawiające państwo monopolu oświatowego i tworzące warunki do poszerzania oferty kształcenia i wychowania instytucjonalnego oraz podnoszenia ich jakości ${ }^{4}$.

Szkoła, w znaczeniu wywiedzionym z greckiego rodowodu, to zorganizowany sposób spędzania czasu; wyraz scholé oznaczał pierwotnie czas wolny, a potem zabawianie się dysputą w czasie wolnym. Na szkołę można spojrzeć z kilku perspektyw, a mianowicie:

a) organizacyjnej: szkołę można przyrównać do instytucji, która rządzi się własnymi prawami i regułami, wytwarza wspólny produkt oraz dotyczy ludzi połączonych więzami instytucjonalnymi;

b) socjologicznej: sposób w jaki rozumie się zależność między szkołą a społeczeństwem;

c) ideologii edukacyjnych, które determinują kształt i obraz szkoły funkcjonującej w danym państwie ${ }^{5}$.

Szkoła jest tworem wielowarstwowym. Można na nią patrzeć $\mathrm{z}$ wielu perspektyw. Zatem budynek szkolny można potraktować jako repetytorium różnych funkcji szkoły rozumianej jako element kultury, jak i namacalną, „rzeczową” realność. W tym też kontekście - jak stwierdza Aleksander Na-

${ }^{4}$ Por. Pedagogika. Leksykon PWN, red. Bogusław Milerski, Bogusław Śliwerski (Warszawa: Wyd. Naukowe PWN, 2000), 227-228.

${ }_{5}^{5}$ Por. Beata Adrjan, Kultura szkoły. W poszukiwaniu nieuchwytnego (Kraków: Impuls, 2011), 15. 
laskowski - szkoła jako repetytorium metafor może być opisywana jako: miejsce spotkań, plac gry, teatr, świątynia, koszary, rodzina, fabryka, amalgamat znaczeń. Cała głębia i realność tej instytucji to szkoła jako miejsce istniejące $\mathrm{w}$ różnych przestrzeniach naraz. Tu bowiem dochodzi do przenikania i nakładania się kolejnych półprzezroczystości, które składają się na wielowymiarowy i przestrzenny obraz każdej placówki oświatowej ${ }^{6}$.

Szkoła jako instytucja społeczna zmienia się wraz z kontekstem jej funkcjonowania. Rdzeń zmiany (kierunek) można określić jako poszukiwanie modelu szkoły sprzyjającego rozwojowi zarówno jednostki, jak i społeczeństwa (uwzględniającego interesy społeczeństwa i jednostki). Na przestrzeni minionego wieku obserwujemy balansowanie między koncepcją urabiania jednostki według potrzeb społeczeństwa i reprodukowania w ten sposób stałych wartości kulturowych a wzorem progresywistycznym, akcentującym konieczność edukowania człowieka do zmieniającego się świata, nieustannego odkrywania go ${ }^{7}$.

Oczywiście, w praktyce czyste typy szkół spotyka się rzadko.

Początki zastosowań pojęcia kultury w badaniach edukacyjnej skuteczności szkoły datuje się na przełom lat 80. i 90. ubiegłego wieku. Podobnie jak w wypadku kultury firmy lub korporacji, zakłada się, że kultura szkoły ma związek z jej skutecznością w zakresie osiągnięć szkolnych uczniów, przebiegu kształcenia, postaw wobec zdobywania wiedzy i innych wymiarów funkcjonowania psychospołecznego uczniów, takich jak zdrowie psychiczne lub zachowania problemowe ${ }^{8}$. Kulturową tożsamość szkoły można określić jako zbiór podzielanych przez personel szkoły i jej uczniów częściowo świadomie, a częściowo nieświadomie wartości, norm, symboli i przekonań, które w znaczącym stopniu wyznaczają zachowania kręgów związanych ze szkołą, a także wzmacniają poczucie odrębności i wspólnoty. Na kulturową tożsamość szkoły składa się zwykle kilka podstawowych elementów. Jest to zjawisko wielowarstwowe, a wartości, normy, przekonania i symbole, które leżą u podstaw zachowań kręgów związanych ze szkołą, nie zawsze pokry-

${ }^{6}$ Por. Aleksander Nalaskowski, Przestrzenie i miejsca szkoły (Kraków: Oficyna Wydawnicza „Impuls”, 2002), 7-9.

7 Bogusława Dorota Gołębniak, „Szkoła wspomagająca rozwój”, w: Pedagogika. Podręcznik akademicki, red. Zbigniew Kwieciński, Bogusław Śliwerski (Warszawa: Wydawnictwo Naukowe PWN, 2003), 122.

${ }^{8}$ Por. Krzysztof Ostaszewski, „Kultura szkoły a zachowania ryzykowne uczniów”, Edukacja 1 (2014): 14. 
wają się z wartościami i normami deklarowanymi w oficjalnych dokumentach i deklaracjach szkoły9.

Kultura organizacyjna oferuje wspólny system znaczeń i jednocześnie odróżnia jedną organizację od drugiej. Kultura organizacyjna spełnia dwie podstawowe funkcje. Informuje osoby spoza przedsiębiorstwa o tym, kim są pracownicy i co reprezentują, oraz jest swoistym kodeksem wzorów zachowań i wzajemnych relacji ${ }^{10}$. Mówiąc o szkole jako organizacji, można wyróżnić:

- wytwory materialne i symboliczne: zalicza się tu architekturę budynku szkoły, strukturę organizacyjną, utrwalone wzory zachowań, historie z życia szkoły, symbolikę i rytuały;

- pożądane wartości, normy, standardy i cele: wyrażają one to, czego szkoła oczekuje od swoich uczniów i nauczycieli;

- podstawowe przekonania, sposoby myślenia, przyjęte ideologie: mają one istotny wpływ na organizację struktury szkoły i na jej aksjologię $^{11}$.

Kultura szkoły to wspólne przekonania i wartości, które są ,,spoiwem” tworzącym ze szkoły jeden organizm. Wynikają one z określonego systemu społecznego i prawnego, wewnętrznej struktury szkoły, działań dyrektora i nauczycieli. Na kulturę szkoły składają się:

- struktura szkoły, cechy socjodemograficzne uczniów i nauczycieli,

- architektura /wyposażenie/, oferta pozalekcyjna,

- przekonania, wartości,

- wzory zachowań,

${ }^{9}$ Por. Jerzy Szczupaczyński, Edukacja a zarzqdzanie (Pułtusk: Wyższa Szkoła Humanistyczna im. Aleksandra Gieysztora, 2004), 43-44. W literaturze funkcjonuje kilka ogólnych definicji kultury szkoły, a mianowicie: a) kultura szkoły składa się ze wspólnie podzielanych przekonań i wartości, które spajają społeczność szkolną w jeden organizm; b) kultura szkoły jest rodzajem obiektywu, przez który członkowie społeczności szkolnej widzą siebie i świat dookoła; c) kultura szkoły składa się z niepisanych zasad i tradycji, norm i oczekiwań, które nadają ramy wszystkiemu - jak ludzie się zachowują, ubierają, o czym rozmawiają, czy szukają pomocy u kolegów, czy tego nie robią, jak nauczyciele traktują swoją pracę i uczniów. Por. Ostaszewski, „Kultura”, 15.

${ }^{10}$ Por. Patricia Buhler, Zarzadzanie (Gliwice: Wydawnictwo Helion, 2002), 235-242.

11 Por. Ostaszewski, „Kultura”, 16. 
- $\quad$ sposoby rozwiązywania problemów podzielane przez członków społeczności szkolnej ${ }^{12}$.

Najbardziej rozpowszechnionym sposobem myślenia o kulturze organizacyjnej szkoły jest model kliniczny Edgara Scheina. W modelu tym kultura składa się z kilku poziomów wyodrębnionych ze względu na trwałość i widoczność. Pierwszy poziom to artefakty (językowe, behawioralne i fizyczne), drugi - normy i wartości, trzeci, stanowiący podłoże kultury - to założenia. Schein podzielił założenia kultury organizacyjnej szkoły na pięć umownych grup:

1) założenia w sprawie związków szkoły $\mathrm{z}$ otoczeniem - dają odpowiedź, jaki jest obraz szkoły i jej misja, jakie ma ona kontakty ze światem zewnętrznym, jak strzeże swoich granic, dla kogo je otwiera i czy jest uzależniona od otoczenia;

2) założenia o naturze ludzkich działań przybliżają obowiązującą w szkole wizję człowieka (np. w co szkoła chce wyposażyć ucznia);

3) założenia w sprawie prawdy i czasu - czy prawda ma w szkole charakter obiektywny, czy subiektywny oraz czy sposób podejścia do czasu koncentruje się na przeszłości, teraźniejszości, a może przyszłości;

4) założenia o naturze ludzkiej - zestaw przekonań o uczniu: jaki on jest, w jaki sposób można go kształtować;

5) założenia o związkach między ludźmi - ukazuje hierarchię władzy, pozycje poszczególnych osób w społeczności szkoły oraz więzi społeczne, które w niej istnieją ${ }^{13}$.

Kultura organizacji w dużym stopniu definiuje zachowania jej członków, stanowi klucz do ich interpretacji. Poznanie kultury umożliwia zatem lepszy wgląd w rozumienie ludzkich zachowań. Silna tożsamość kulturowa szkoły zapewnia osobom z nią związanym poczucie przynależności i misji, buduje poczucie wspólnotowości, zwiększa poczucie lojalności wobec szkoły i identyfikacji z nią.

${ }^{12}$ Katarzyna Okulicz-Kozaryn, Klimat i kultura szkoty a zdrowie psychiczne uczniów i nauczycieli, https://www.ore.edu.pl/index.php?...i-kultura...i... (05.05.2015).

${ }_{13}$ Por. Adrjan, Kultura, 56-57. 


\section{Tożsamość szkoły katolickiej}

Szkoła katolicka jest strukturą społeczną mającą swoje charakterystyczne cele i metody działania, które jednak nie odbiegają w sposób zasadniczy od celów i metod działania każdej innej szkoły. W świetle nauki Soboru Watykańskiego II wyrażonej w Deklaracji o wychowaniu chrześcijańskim Gravissimum educationis szkoła katolicka:

nie mniej niż inne szkoły zdąża ona do celów kulturalnych i do prawdziwie ludzkiej formacji młodzieży. Właściwością zaś jej jest to, że stwarza w społeczności szkolnej atmosferę przesiąkniętą ewangelicznym duchem wolności i miłości, dopomaga młodzieży, aby w rozwijaniu własnej osobowości wzrastała zarazem wedle nowego stworzenia, którym stała się przez chrzest, a całą ludzką kulturę porządkuje ostatecznie zgodnie z orędziem zbawienia, tak aby poznanie, które wychowankowie stopniowo zdobywają odnośnie do świata, życia i człowieka, było oświetlone wiarą (DWCH 8$)^{14}$.

Szkoła katolicka musi więc spełniać wymagania stawiane jej przez dwie instytucje, a mianowicie przez państwo i przez Kościół. Aby mogła w ogóle powstać, musi mieć zatem odpowiednią zgodę władzy świeckiej ${ }^{15}$, natomiast aby była szkołą katolicka, powinna spełniać określone wymagania stawiane jej w tym względzie przez Kościół. W tym też kontekście Kodeks Prawa Kanonicznego stwierdza, że „Szkołę wtedy uważa się za katolicką, gdy jest kierowana przez kompetentną władzę kościelną albo kościelną osobę prawną publiczna, albo za katolicką została uznana przez władzę kościelną dokumentem na piśmie. [...] Żadna szkoła, chociażby rzeczywiście była katolicka, nie może nosić nazwy szkoła katolicka bez zgody kompetentnej władzy kościelnej"16.

Dokumenty Soboru Watykańskiego II, Kongregacji Wychowania Katolickiego, Kodeks Prawa Kanonicznego oraz Wytyczne Konferencji Episko-

14 Sobór Watykański II, „Deklaracja o wychowaniu chrześcijańskim Gravissimum educationis", w: Sobór Watykański II. Konstytucje, Dekrety, Deklaracje (Poznań: Pallottinum, 1986) - w tekście DWCH z odnośnym numerem.

15 System oświaty w Rzeczypospolitej Polskiej umożliwia zakładanie i prowadzenie szkół i placówek oświatowo-wychowawczych przez różne podmioty, w tym również przez kościelne osoby prawne. Por. Ustawa o systemie oświaty, Dz. U 1991, nr 95, poz. 425, z poźn. zm., art. 1, pkt 3; art. 5, ust. 1 i 2, pkt 3 i 4.

${ }^{16}$ Kodeks Prawa Kanonicznego (Poznań: Pallottinum, 1984), kan. 803, § 1 i § 3. 
patu Polski dla szkół katolickich w Polsce przyznają szkole katolickiej swoistą specyfikę, tożsamość, autonomię, odróżniając ją od pozostałych instytucji kościelnych działających na rzecz wychowania. Dokumenty powyższe określają, że szkoła katolicka jest jednocześnie szkoła w pełnym tego słowa znaczeniu oraz szkołą katolicka, gdyż jest wspólnotą chrześcijańską, której program wychowawczy zakorzeniony jest w Chrystusie i Jego Ewangelii. Szkoła katolicka, „to, co ją określa w tym znaczeniu, jest jej odwołanie się do chrześcijańskiej koncepcji rzeczywistości. To Chrystus stanowi centrum tej koncepcji" "17. Szkoła katolicka jako miejsce integralnego kształtowania osoby ludzkiej poprzez jasny program wychowawczy, którego fundamentem jest Chrystus; tożsamość eklezjalna i kulturalna szkoły katolickiej; jej misja wychowania przez miłość; jej służba społeczna; styl wychowawczy, jaki powinien charakteryzować wspólnotę wychowującą - to zasadnicze aspekty szkoły katolickiej, które są istotne dla skuteczności jej wychowawczej roli w Kościele i społeczeństwie ${ }^{18}$. Odwołanie się do Chrystusa, w którym wszystkie wartości ludzkie znajdują swą pełną realizację i harmonijną jedność, sprawia, że szkoła katolicka zobowiązuje się świadomie do wychowania człowieka integralnego: „Szkoła Katolicka uważa za swój obowiązek - i to z nowego tytułu wobec braków dzisiejszej rodziny i społeczeństwa w tej dziedzinie - integralnego kształtowania osobowości chrześcijańskiej. [...] naucza młodzież wyjaśniać język wszechświata, który objawia Stwórcę i poprzez postęp nauki lepiej poznawać Boga i człowieka"19. Świadomość ta oznacza postawienie osoby ludzkiej w centrum założeń i oddziaływań wychowawczych.

W dokumencie Kongregacji ds. Wychowania Katolickiego Świecki katolik świadkiem wiary $w$ szkole czytamy, że:

do szkoły należy szczególnie troskliwe rozwijanie zdolności intelektualnych, twórczych i estetycznych człowieka, właściwe kształtowanie osądu, woli i uczciwości, rozwijanie poczucia wartości, umacnianie słusznych postaw i mądrych zachowań, wprowadzanie w dziedzictwo kulturowe, odziedziczone po

17 Kongregacja Nauczania Katolickiego, „Szkoła katolicka” (Rzym 19.03.1977), w: Paideia chrześcijańska. Cz. 1: Wychowanie człowieka w nauczaniu Kościoła (Warszawa: Ośrodek Działalności Kulturalnej i Edukacji Narodowej, Stowarzyszenie PAX, 1977), 33.

18 Kongregacja ds. Wychowania Katolickiego, ,Szkoła katolicka u progu trzeciego tysiąclecia” (Rzym 28.12.1997), w: Szkoła miejscem ksztattowania postawy patriotycznej (Częstochowa: Biblioteka „Niedzieli”, 1997), 4.

19 Kongregacja Nauczania Katolickiego, ,Szkoła katolicka”, 45-46. 
przeszłych pokoleniach, przygotowanie do życia zawodowego, kształtowanie wśród uczniów o rożnych charakterach i pochodzeniu społecznym ducha braterstwa, który prowadzi do wzajemnego zrozumienia ${ }^{20}$.

Oznacza to, że szkoła nie może być zredukowana tylko do przekazu wiedzy lub tylko do kształtowania umiejętności, lub tylko do wychowania. Usytuowanie ucznia w centrum działalności szkolnej oraz rozszerzenie zadań edukacyjnych nauczyciela powoduje, że nie szkoła jako instytucja, a nauczyciel i uczeń-wychowanek stają się rzeczywistymi i pierwszoplanowymi podmiotami działalności edukacyjnej.

Szkołę katolicką określa odniesienie do osoby. „Każda osoba, z jej potrzebami materialnymi i duchowymi, stoi w centrum nauczania Jezusa; dlatego promocja osoby ludzkiej stanowi cel katolickiej szkoły". Stwierdzenie to ukazuje żywotny związek człowieka z Chrystusem, przypomina, że w Jego Osobie mieści się pełnia prawdy o człowieku. [...] Ta świadomość oznacza postawienie osoby w centrum założeń wychowawczych w szkolnictwie katolickim, wzmacnia gorliwość i uzdatnia do wychowania silnych osobowości ${ }^{21}$.

Odpowiedzialność za wychowanie dzieci spoczywa przede wszystkim na rodzicach. Pierwszymi odpowiedzialnymi za kreowanie oryginalnego stylu chrześcijańskiego w szkole katolickiej są natomiast wychowawcy jako osoby i jako wspólnota. Uczestnictwo w organizacjach, osobiste spotkania i inne inicjatywy mają na celu coraz bardziej aktywne włączanie się rodziców w życie instytucji oraz uwrażliwienie ich w odniesieniu do zadania wychowawczego. Dlatego

szkoły katolickie powinny stać się miejscem spotkania tych, którzy chcą świadczyć o wartościach chrześcijańskich w całym wychowaniu. [...] powinna utworzyć wspólnotę dążącą ostatecznie do przekazywania wartości życiowych. Program bowiem życiowy, który ona proponuje, polega [...] na planie złączenia się przez wiarę z Osobą Chrystusa, który jest miarą wszelkich wartości. Otóż wiara

${ }^{20}$ Kongregacja ds. Wychowania Katolickiego, „Świecki katolik świadkiem wiary w szkole" (Rzym, 15.10.1982), w: Paideia chrześcijańska. Cz. 1: Wychowanie człowieka w nauczaniu Kościoła (Warszawa: Ośrodek Działalności Kulturalnej i Edukacji Narodowej, Stowarzyszenie PAX, 1982), 12.

${ }^{21}$ Kongregacja ds. Wychowania Katolickiego, ,Szkoła katolicka u progu”, 9. 
aktualizuje się w spotkaniu z osobami i wspólnotami, które żyją wiarą. Wiara chrześcijańska rodzi się i wzrasta w łonie wspólnoty ${ }^{22}$.

Wynika więc stąd konieczność współpracy i szeroko pojętego współdziałania oraz ukazywania tych samych wartości przez rożne środowiska, mające wpływ na rozwój osobowości młodego człowieka. Jak stwierdza Jan Paweł II:

Szkoła katolicka, która nie tylko naucza doktryny, ale stwarza także środowisko wychowawcze, umożliwiające przeżycie doświadczenia wspólnoty wiary, modlitwy, służby, może odegrać ważną, a nawet decydującą rolę w zapewnieniu młodym ludziom życiowej orientacji, czerpiącej inspirację z mądrości Ewangelii. Świadectwo wspólnoty wychowawczej pozostające w harmonii z wytwarzanym przez szkołę klimatem wiary składa się na ową szczególną posługę, którą szkoła katolicka może oddać chrześcijańskiemu wychowaniu młodzieży. Jej działalność okaże się bardziej skuteczna wówczas, gdy będzie koordynowana z oddziaływaniem rodziny, z którą nawiąże bezpośredni kontak $\mathrm{t}^{23}$.

Szkoła katolicka ma niejako podwójny cel i wymiar działania, odpowiednio do przyjętego w nauczaniu Kościoła prawa wszystkich ludzi do wychowania. Ma zapewnić formację ludzką i chrześcijańską. W tym też kontekście można określić zasadnicze cele szkoły katolickiej, którymi są:

1. uświadomienie wychowankom ich osobowej godności, jako obrazu Boga i osobowej struktury; motywowanie ich do rozwijania własnego człowieczeństwa rozumianego w sposób osobowy poprzez wspomaganie rozwoju fizycznego, intelektualnego, moralnego, społecznego, kulturalnego, estetycznego oraz poprzez rozwój duchowy - jako świadomą orientację na wartości duchowe, głównie prawdę, dobro, piękno, a w ujęciu chrześcijańskim - na zwieńczająca je świętość;

2. kształcenie postaw szacunku, miłości, gotowości do pomocy i ofiarnej służby drugiemu i innym we wspólnocie, przede wszystkim we wspólnotach naturalnych - w rodzinie, narodzie, we wspólnotach

${ }^{22}$ Kongregacja Nauczania Katolickiego, „Szkoła katolicka”, 53.

23 Jan Paweł II, „Zadania szkoły. List na Światowy Dzień Modlitw o Powołania Kapłańskie i Zakonne, Watykan, 2 lutego 1989", L'Osservatore Romano (wyd. polskie) 1-2 (1989): 25. 
życiowych - państwowej, kulturowej, ludzkiej, oraz we wspólnotach z wyboru: religijnych, zawodowych, sytuacyjnych;

3. kształcenie tożsamości kulturowej oraz odpowiedzialności za kulturę i aktywnej obrony wartości z nią związanych;

4. stwarzanie poprzez odpowiedni poziom, wymagania i zachętę warunków wewnętrznych i zewnętrznych sprzyjających rozwojowi osobowemu i religijnemu;

5. przygotowanie do kompetentnego i krytycznego korzystania z osiągnięć cywilizacyjnych, traktowania ich jako środków do rozwoju osobowego;

6. formowanie religijne uczniów wierzących-katolików oraz zapoznawanie z religią katolicką uczniów innych wyznań i niewierzących, a także przygotowanie wychowanków do odpowiedzialnego udziału w życiu Kościoła.

Działalność szkoły wynika z ujmowania siebie, innych, świata w świetle wiary katolickiej. Ideałem w szkole katolickiej jest więc człowiek osobowo dojrzały, a dla osób ochrzczonych - świadomy swej wiary chrześcijanin. Ponadto cele powyższe stanowią podstawowy wymiar aksjologii szkoły katolickiej. Ważne jest zatem kultywowanie tradycji szkoły, wyjaśnianie i pielęgnowanie obrzędowości, przyjęcie symboli związanych ze szczególnie cenionymi wartościami, takimi jak: patron szkoły, sztandar, pamiątki ${ }^{24}$.

W dziejach Kościoła szkoła katolicka znana jest przede wszystkim z działalności zakonów. Osoby obdarzone danym charyzmatem wnoszą do szkoły bogactwo własnej tradycji wychowawczej, opartej na autentycznym charyzmacie, ubogacając środowisko szkolne wartościami swej wspólnoty. Zadanie dzielenia się duchowością komunii w ramach wspólnoty szkolnej zakorzenia się w byciu częścią Kościoła-komunii. Zadanie wychowawcze, zarówno w szkołach katolickich, jak i w innych typach szkół, jest dla osób konsekrowanych powołaniem i wyborem życiowym, drogą świętości, wymogiem sprawiedliwości i solidarności. Takie współdziałanie, oprócz uczynienia bardziej specjalistyczną służby wychowawczej, stwarza warunki do dzielenia się charyzmatami na rzecz całego Kościoła. To przekonanie uwidacznia się w zadaniu kształtowania życia wspólnoty jako miejsca wzrostu osób oraz wzajemnej pomocy w poszukiwaniu i wypełnianiu wspólnej misji. Tak więc z racji swego powołania osoby konsekrowane angażują się w promocję godności osoby ludzkiej, współpracując, aby szkoła stała się miej-

${ }^{24}$ Por. Katarzyna Olbrycht, „Aksjologia szkoły katolickiej”, Ethos 75 (2006), 94-97. 
scem wychowania integralnego, ewangelizacji i uczenia się żywego dialogu między osobami należącymi do różnych kultur, religii i środowisk społecznych ${ }^{25}$.

\section{Kultura szkoły w pedagogii salezjańskiej}

Wychowanie zawsze odbywa się w konkretnym miejscu i bierze pod uwagę zróżnicowane sytuacje.

Bezpośrednimi wychowawcami w stosunku do swoich dzieci pozostają zawsze na pierwszym miejscu rodzice. Rodzice mają też $\mathrm{w}$ tej dziedzinie pierwsze i podstawowe uprawnienia. Sq wychowawcami, ponieważ sq rodzicami. Jeśli zadanie to rodzice z kolei dzielą z innymi ludźmi, a także z instytucjami, na przykład z Kościołem i państwem, to zawiera się w tym prawidłowe odzwierciedlenie zasady pomocniczości. [...] W tych dziedzinach, gdzie rodzina nie może skutecznie działać sama, zasada pomocniczości wspiera miłość rodzicielską, odpowiada dobru rodziny. Pomocniczość dopełnia w ten sposób miłość rodzicielską, a równocześnie potwierdza jej fundamentalny charakter. Wszyscy inni uczestnicy procesu wychowawczego działają poniekąd $w$ imieniu rodziców, w oparciu o ich zgodę, a w pewnej mierze nawet ich zlecenie ${ }^{26}$.

Szkoła jest tą instytucją, która kontynuuje zadania rodziny, przede wszystkim w wymiarze wychowawczym i socjalizującym. Szkoła - jak czytamy w dokumentach Soboru Watykańskiego II - mocą swego posłannictwa kształtuje władze umysłowe, rozwija zdolność wydawania prawidłowych sądów, wprowadza w dziedzictwo kultury wytworzonej przez przeszłe pokolenia, kształci zmysł wartości, przygotowuje do życia zawodowego, sprzyja dyspozycjom do wzajemnego zrozumienia się, stwarzając przyjazne współżycie wśród wychowanków różniących się charakterem i pochodzeniem. Jest powołana, by każdemu dać szansę kształtowania własnej osobowości, życia moralnego i duchowego, zrealizowania wszystkich swoich możliwości i zdolności a także włączenia się w społeczeństwo (por. DWCH 5).

${ }^{25}$ Kongregacja Wychowania Katolickiego, Osoby konsekrowane i ich misja w szkole. Refleksje i wskazania (Poznań: Pallottinum, 2003), 50-51; Kongregacja ds. Wychowania Katolickiego, „Szkoła katolicka u progu”, 13-15.

${ }^{26}$ Jan Paweł II, List do rodzin (Wrocław: Wydawnictwo Wrocławskiej Księgarni Archidiecezjalnej, 1994), 16. 
Obok wpływu wychowawczego rodziny - podkreśla Jan Paweł II - trzeba podkreślić działalność szkoły, otwierającej horyzonty bardziej rozległe i uniwersalne. Według koncepcji księdza Bosco szkoła, oprócz przyczyniania się do rozwoju kulturalnego, społecznego i zawodowego młodzieży, powinna jej dostarczyć odpowiedniego zasobu wartości i zasad moralnych. W przeciwnym razie byłoby niemożliwe konsekwentne, pozytywne i uczciwe życie i działanie w społeczeństwie pełnym napięć i konfliktów ${ }^{27}$.

System prewencyjny św. Jana Bosko powstał jako odpowiedź na potrzeby wychowawcze związane z konkretnym środowiskiem ubiegłego wieku we Włoszech. Jest to synteza jego myśli pedagogicznej, u podstaw której znajduje się idea całościowości, dążenie do integralności i złożoności rzeczywistości i zjawisk, przybierając w końcu postać ogólnej teorii systemowej dla interpretowania myślenia, świadomości, życia społecznego i kultury. Dzieło wychowawcze Jana Bosko kontynuowane jest w Rodzinie Salezjańskiej i całym Kościele oraz cieszy się zainteresowaniem i uznaniem pedagogów i wychowawców. Rodzina Salezjańska św. Jana Bosko jest zjednoczeniem wspólnot, instytutów zakonnych i świeckich oraz grup apostolskich, które żyją tym samym duchem salezjańskim, wywodzącym się od św. Jana Bosko, podejmują w różnych zakresach to samo posłannictwo młodzieżowe, zobowiązują się do wzajemnej współpracy i współdziałania. W świecie istnieje 29 grup Rodziny Salezjańskiej zrzeszających ponad czterysta tysięcy członków ${ }^{28}$.

„Charyzmat księdza Bosko - dar Ducha Świętego dla Kościoła - jest zasadą, która inspiruje wszelki salezjański zapał względem młodzieży. Także z tego powodu jego urzeczywistnienie pod postacią służby wychowawczej musi wyróżniać się pod względem jakości edukacyjnej, bez której nie byłoby możliwe zachowanie wierności ks. Bosko"29. Wychowanie to ma być służbą we wspólnocie kościelnej i na rzecz tejże wspólnoty. W tym też kontekście dokumenty Towarzystwa Salezjańskiego podkreślają, że szkoła

27 Jan Paweł II, Iuvenum patris. List Ojca Świętego Jana Pawła II do księdza Egidio Viganó Przełożonego Generalnego Towarzystwa św. Franciszka Salezego w setna rocznice śmierci św. Jana Bosko (Rzym: Tipografia Poliglotta Vaticana, 1988), 18.

${ }_{28}$ Por. Marian Nowak, „Laudacja”, w: Ks. Pascual Chávez Villanueva SDB, generat Towarzystwa św. Franciszka Salezego: doktor honoris causa Katolickiego Uniwersytetu Lubelskiego Jana Pawła II (Lublin: KUL, 2011), 42-43; www.sdb.org.pl/15.05.2015.

${ }_{29}$ Pascual Chavez Villanueva, „Salezjańska służba młodzieży na polu edukacji”, w: Ks. Pascual Chávez Villanueva SDB, generat Towarzystwa św. Franciszka Salezego: doktor honoris causa Katolickiego Uniwersytetu Lubelskiego Jana Pawła II (Lublin: KUL, 2011), 64. 
salezjańska powstała w Oratorium na Valdocco (Turyn), aby odpowiedzieć na konkretne potrzeby młodzieży i włączyć się w powszechny program wychowania i ewangelizacji młodzieży, szczególnie najuboższej. Szkoła zatem jest miejscem, w którym urzeczywistnia się kulturę, uczy krytycznego spojrzenia na otaczający świat, udziela usystematyzowanej odpowiedzi na potrzeby wieku dorastania, przekazuje koncepcję świata, człowieka i historii. Tożsamość i specyfikę szkoły salezjańskiej określa się poprzez wyjaśnienie podstawowych pojęć - szkoła, katolickość, salezjańskośćc ${ }^{30}$.

Myśl profetyczna założyciela Zgromadzenia jest charyzmatem, który sprawia, że szkoła jest „katolicką”, ale jednocześnie jednym z rodzajów szkół katolickich. Uznanie istnienia wielości powołań w Kościele nadaje nowe znaczenie obecności osób z różnych zgromadzeń zakonnych (osób konsekrowanych) w obszarze wychowania szkolnego. Specyfika ich życia polega na byciu znakiem, pamięcią i proroctwem wartości Ewangelii. Historia Kościoła bogata jest we wspaniałe przykłady osób konsekrowanych, które wyrażały i nadal wyrażają swoje dążenie do świętości przez pracę pedagogiczną, ukazując zarazem świętość jako cel wychowania ${ }^{31}$. Szkoła salezjańska jest osadzona w posłannictwie Kościoła.

Nasze posłannictwo - czytamy w Konstytucjach Towarzystwa św. Franciszka Salezego - uczestniczy w misji Kościoła, który niosąc ludziom orędzie Ewangelii, ściśle złączone z rozwojem porządku doczesnego, realizuje zbawczy plan Boga: przyjścia Jego królestwa. Wychowujemy i ewangelizujemy zgodnie z programem integralnego rozwoju człowieka, ukierunkowanym na Chrystusa, Człowieka doskonałego. Wierni intencjom naszego Założyciela, pragniemy wychowywać „uczciwych obywateli i dobrych chrześcijan”32.

Tak sformułowana misja szkoły salezjańskiej jest podstawowym narzędziem kształtowania jej kulturowej tożsamości, określa bowiem podstawowe cele, wartości i zasady działania, wyrażone w specyficzny sposób, które orientują codzienną jej aktywność. A zatem:

${ }^{30}$ Por. Salezjańskie duszpasterstwo młodzieżowe. Podstawowe punkty i odniesienia (Kraków: Salezjańskie Centrum Wychowania i Duszpasterstwa 1999), 68-71; Kazimierz Misiaszek, „Pedagogia salezjanów (Towarzystwa Św. Franciszka Salezego)”, w: Pedagogie katolickich zgromadzeń zakonnych. Historia i wspótczesność, t. 1, red. Janina Kostkiewicz (Kraków: Wydawnictwo Impuls, 2012), 256-266.

31 Szerzej na ten temat: Kongregacja Wychowania Katolickiego, Osoby, 15-21.

${ }^{32}$ Konstytucje Towarzystwa św. Franciszka Salezego (Rzym: S.G.S. Istituto Pio XI, 1986), 31 . 
a) szkoła salezjańska, wpisana w posłannictwo Kościoła, realizuje integralny charakter wychowania szkolnego i ma walor humanistyczny. Osobowe wychowanie czlowieka, uwzględniające sposób istnienia i działania człowieka jako osoby, ma prowadzić do kształtowania ludzi wolnych i świadomie odpowiedzialnych za swój byt i przeznaczenie. Założenia o ludzkiej naturze przynoszą wiedzę o tym, co szkoła ma nadzieję dać swoim uczniom i w którym kierunku pragnie ich prowadzić. Oferując młodemu człowiekowi podstawowe instrumenty do życia, usposabia go jednocześnie do podmiotowego i odpowiedzialnego działania w każdej rzeczywistości. „System zapobiegawczy, już z samej nazwy, wymaga troskliwego zajęcia się poszczególnymi «osobowościami» wychowanków, w których każdy znajduje się w centrum procesu wychowawczego, polegającego na zachęcaniu, dawaniu propozycji, otwieraniu możliwości, dokonywaniu wyborów i podejmowaniu decyzji" ${ }^{3}$. W wychowaniu według księdza Bosko chodziłoby więc o rzeczywiste spotkanie z młodym człowiekiem, przyjęcie i zaakceptowanie go, tworzenie środowiska bogatego w wartości ludzkie i personalną relację wychowawczą. „Oczywiście, taki system wymaga od wychowawcy przeświadczenia, że w każdym młodym człowieku, nawet jeśli wywodzi się z marginesu społecznego lub jest wykolejony, tkwią zadatki dobra, które - gdy są odpowiednio rozbudzane - mogą wprowadzić na drogę wiary i uczciwego życia" 34 .

b) zbadanie różnych definicji, które proponuje się na zdefiniowanie szkoły, pozwala określić szkołę jako miejsce integralnej formacji osoby, poprzez systematyczną i krytyczną asymilację kultury. Spójne, krytyczne i oceniające przekazywanie kultury ma przedstawiać cały szereg wartości i ich przeciwstawieństw, ukazać hierarchię dóbr kulturalnych. Aby tworzyć kulturę, trzeba do końca integralnie widzieć człowieka jako szczególną, samoistną wartość, jako podmiot związany z osobową transcendencją. Tak więc zarówno dobór treści programowych, jak i sposób ich realizacji powinien obejmować przekaz prawdy i wiedzy oraz ukazywać powiązania między kulturą i wiarą. ,Wychowanie - według księdza Bosko - wymaga szczególnej postawy wychowawcy i całego zespołu sposobów i poczynań, opartych na przekonaniach płynących $\mathbf{z}$ rozumu i wiary, które kierują działaniem wychowawczym" ${ }^{35}$. Przekonanie o tym zawarł, formułując zasady systemu

${ }^{33}$ Luciano Cian, System zapobiegawczy św. Jana Bosko i jego charakterystyka (Warszawa: Wydawnictwo Salezjańskie, 2001), 24.

34 Jan Paweł II, Iuvenum, 8.

35 Tamże, 9. 
prewencyjnego, który - jak pisał - opiera się całkowicie na „rozumie, religii i miłości wychowawczej”. W religii widział przede wszystkim droge do serca, umysłu i duszy młodego człowieka oraz pomoc w osiaganiu pełni osobowego rozwoju człowieka. To religia motywuje człowieka do dobra, ukazuje sens jego życia i poświęcenia, zachęca do działania na rzecz dobra wspólnego. Rozumna religia i rozumna miłość wychowawcza (dobroć) mają być zasadami, którymi ma kierować się wychowawca. Rozumność życia religijnego przejawia się między innymi w tym, że unika się redukowania religii do sfery tylko przeżyć, jak i odwrotnie do sfery rozumu i nauczania reguł, zasad i definicji. W rozumnym podejściu do religii dąży się do ujaśnienia sensu nauczanych prawd religijnych i ich praktykowania w codziennym życiu ${ }^{36}$. Ksiądz Bosko otwierał serca swoich wychowanków i współpracowników na rzeczywistość Kościoła.

c) zadaniem szkoły jest proponować obraz i doświadczenie wspólnoty osób, gdzie, respektując odmienność ról i kompetencji, młodzi mogą nauczyć się współuczestnictwa, demokracji, osobowej odpowiedzialności w pracy, wrażliwości na drugiego człowieka, szczególnie na mniej uzdolnionego lub przeżywającego szczególne trudności i problemy. W taki sposób szkoła będzie mogła stać się wspólnotą wychowującą wokół wartości programowych akceptowanych w dialogu ze społecznością lokalną. Wspólnota wychowawcza charakteryzuje się nie tyle organizacją, strukturami i funkcjami, co raczej duchem, który ją przepaja, i klimatem rodzinnym, a tym samym jest ona konkretnym wyrazem salezjańskiej obecności, którą Jan Bosko widział jako rodzinę, to znaczy wspólnotę osób, które podzielają misję wychowania młodzieży. Popierając wielorakie formy działania, tworzył on środowiska życia, dobrego wykorzystania wolnego czasu, apostolatu, nauki, modlitwy, radości, zabawy i kultury, gdzie młodzi mogli odnajdywać samych siebie i rozwijać się. W tym też kontekście

na określenie poprawnej relacji pomiędzy wychowawcami a wychowankami ksiądz Bosko lubił używać terminu familiaritá (zażyłość, przyjaźń). Długoletnie doświadczenie przekonało go, że bez tej zażyłości nie można okazać miłości, a bez tego trudno o wzbudzenie zaufania, które jest niezbędnym warunkiem skuteczności pracy wychowawczej. Ogół celów, które należy osiągnąć,

36 Por. Andrzej Maryniarczyk, „Religia w posłudze wychowawcy: anachronizm czy niezbywalny wymóg?", w: Wspótczesny wychowawca w stylu księdza Bosko, red. Józef Wilk (Lublin: Poligrafia Inspektoratu Towarzystwa Salezjańskiego, 1998), 107-114. 
program, wskazania metodologiczne stają się konkretne, jeśli są nacechowane szczerym duchem rodzinnym, tzn. jeśli będą przeżywane w środowisku radosnym, pogodnym i mobilizującym ${ }^{37}$.

d) ksiądz Bosko stworzył szkołę wychowania i był w niej mistrzem, mistrzem w nawiązywaniu kontaktów z wychowankami, w uczestnictwie w ich życiu i w ich drodze formacyjnej. W takim klimacie ,pedagogicznej obecności - asystencji”" znamienne są słowa Jana Bosko, będące kwintesencją wychowania: ,Jest mi tu dobrze z wami, przebywanie $\mathrm{z}$ wami to moje życie"38. Asystencja, rozumiana jako element salezjańskiego systemu prewencyjnego, to zatem nieustanna i życzliwa obecność wychowawcy, świadcząca o miłości Boga do człowieka, wspierająca, okazująca sympatię i gotowa do dialogu. Asystencja była i jest obecna w dwóch zasadniczych filarach pedagogiki zapoczątkowanej przez św. Jana Bosko: w milości i w dialogu z wychowankiem. Pojęcie to doprecyzowuje słynnym zdaniem, że „nie wystarczy kochać (abstrakcyjnie) młodych ludzi, potrzeba by oni wiedzieli, że są kochani”. Zwracał uwagę na to, co zbliża, wzajemnie otwiera i łączy ludzi, co buduje dialog i nasyca go treścią: koleżeństwo, zabawę, radość, sport, śpiew, pracę i modlitwę. Łączy profesjonalny racjonalizm ze sferą emocji, realia społeczne z ideałami, praktykę wychowawczą z refleksją nad człowiekiem, świat widzialny w wymiarach „tu i teraz” z rzeczywistością transcendentną ${ }^{39}$.

Uczył wychowawców życia z młodzieżą, bycia obok niej, pracy dla niej na wzór rodziny respektującej własny rytm rozwoju, zdolnej do głębokiego przenikania potrzeb młodych ludzi, rozumienia języka, jakim mówią, dostrzegania ich oczekiwań i pilnej potrzeby otwierania się na nowy świat. [...] Metoda księdza Bosko wywodzi się z uważnej i pełnej miłości obecności dla młodych.

37 Jan Paweł II, Iuvenum, 12.

${ }^{38}$ Luciano Cian, Wychowanie w duchu Księdza Bosko (Warszawa: Wydawnictwo Salezjańskie, 1990), 196.

${ }^{39}$ Guido Gatti, „Tradycja wychowawcza ks. Bosko dzisiaj: konieczność wychowawcy”, w: Współczesny wychowawca w stylu księdza Bosko, red. Józef Wilk (Lublin: Poligrafia Inspektoratu Towarzystwa Salezjańskiego, 1998), 67-81; Barbara Smolińska-Theiss, Wiesław Theiss, „Asystencja i dialog pedagogiczny”, w: Jestem wychowawcq. Model pracy z uczniem $i$ klasq szkolnq wedlug systemu prewencyjnego Jana Bosko, red. Kazimierz Franczak (Warszawa: Salezjański Instytut Wychowania Chrześcijańskiego, 2004), 43-53. 
Ta obecność otwiera na poznawanie młodego człowieka, ponieważ postrzega go w środowisku, w którym żyje ${ }^{40}$.

e) znaczenie grup rówieśniczych i stowarzyszeń młodzieżowych w wychowaniu i formacji młodego człowieka. W systemie prewencyjnym Jana Bosko są to stowarzyszenia różnego typu, tworzone ze względu na wiek, kategorię młodych oraz posiadające zróżnicowane cele, w których wzrasta i rozwija się energia i przedsiębiorczość młodzieży. Stowarzyszenia: „Mały Kler, Bractwo św. Ludwika, Przenajświętszego Sakramentu, Niepokalanego Poczęcia - pisał Jan Bosko do dyrektorów salezjańskich - należy je zalecać i promować. Okazuj życzliwość i zadowolenie tym, którzy do nich należą; ale ty będziesz jedynie ich promotorem; te sprawy traktuj jako dzieło młodzieży"41. Były to środowiska życia, dobrego wykorzystania czasu, apostolatu, nauki modlitwy, radości, zabawy i kultury, w których młodzi mogli odnajdywać samych siebie i rozwijać się. W tym też kontekście współczesny nauczyciel (wychowawca) jest zobowiązany do prześledzenia sytuacji i warunków życia i zapewnienia odpowiedniej przestrzeni dla ducha pomysłowości i inicjatywy znamionujących młodzież.

Szkoła jest systemem zorganizowanym. Oznacza to, że zespolone w ramach szkoły działania ludzi nie są przypadkowe, lecz uporządkowane i nakierowane na wspólny cel. Aby szkoła mogła osiagać cele, dla realizacji których została powołana, zachowania tworzących ją osób - przede wszystkim nauczycieli i uczniów - muszą stanowić spójny system działań. Doskonalenie indywidualności, dążenie do prawdy oraz stawanie się człowiekiem otwartym na świat wymaga szczególnej wrażliwości ze strony wszystkich, którzy pracują w szkole. Każdy człowiek jest ze szkołą związany emocjonalnie. Wyrabia sobie od dzieciństwa indywidualnie interpretowaną wizję szkoły, a kolejne życiowe doświadczenia tworzą osobiste koncepcje jej kultury. Tworzyć zatem należy taki model kultury szkoły, której społeczność cechowałyby: kreatywność, otwartość, dynamiczność, refleksyjność, tolerancja i umiejętność wspólnotowego działania. W sytuacjach wychowawczych i w relacjach

40 Severino De Pieri, Ukierunkowanie w wychowaniu i towarzyszenie powołaniu (Warszawa: Wydawnictwo Salezjańskie, 2002), 15-16.

${ }^{41}$ Teresio Bosco, Złote myśli Księdza Bosko (Warszawa: Wydawnictwo Salezjańskie, 2002), 58 
międzypodmiotowych korzystać z metod aktywizujących, pobudzających do refleksji, rozwijających osobowość, wyzwalających uczestnictwo we wspólnocie. Stwarzać uczniowi szansę integralnego rozwoju ${ }^{42}$. Przyszłość jest szansą i możliwością, które wypełnić trzeba określonymi treściami i wartościami. „Wychowanie jest sprawą serca - stwierdza Ksiądz Bosko - i trzeba pozwolić Bogu wejść do serca młodzieży nie tylko przez bramę Kościoła, ale również przez bramy szkoły i warsztatu pracy" ${ }^{\prime 3}$. W tym też kontekście w systemie prewencyjnym nie proponuje się gotowych recept, bezpośredniego przenoszenia stosowanych przez niego metod, ale wzywa do dokonania przemyślanych działań w obszarze wychowania w aktualnym i dobrze rozpoznanym kontekście kulturowym. Poznanie tej sytuacji i oddziaływanie na nią jest podstawowym warunkiem dobrego, to jest skutecznego wychowania.

\section{The Catholic School Culture in the Context of Salesian Pedagogy (Summary)}

Man creates culture, but it shapes his life. The symbol of the place of education in culture is the school. The cultural identity of the school usually consists of a few basic elements. It is a multi-layered phenomenon, and the values, norms, beliefs and symbols that underlie behaviour of circles related to the school do not always coincide with the values and norms declared in the school's official documents and declarations. In the end, the Catholic school organizes the whole of human culture in accordance with the message of salvation, so that the knowledge that pupils gradually acquire with regard to the world, life and humanity, is illuminated by faith. The Salesian School is embedded in the mission of the Church. Documents of the Salesian Society emphasize that the Salesian school was established in the Oratory in Valdocco (Turin) to respond to the specific needs of young people and engage in widespread programme of education and evangelization of the young, especially the poorest. The mission of the Salesian school: To educate "honest citizens and good Christians", is an essential tool for shaping its cultural identity; it sets out the basic objectives, values and principles of action, expressed in a specific way, that orient its daily activity.

42 Adrjan, Kultura, 201; Katarzyna Wereszczyńska, „Wychowanie szkolne - między socjalizacją a indywidualizacją”, w: Wychowanie w szkole: od bezradności ku możliwościom, red. Radosław Chałupniak, Tomasz Michalewski, Ewa Smak (Opole: Redakcja Wydawnictw Wydziału Teologicznego UO, 2014), 111-112.

43 Jan Paweł II, Iuvenum, 20. 
Key words: school; school culture; the Catholic school; preventive system; upbringing.

\section{Kultura szkoły katolickiej w kontekście pedagogii salezjanów (Streszczenie)}

Człowiek tworzy kulturę, ale i ona kształtuje jego życie. Symbolem miejsca edukacji w kulturze jest szkoła. Na kulturową tożsamość szkoły składa się zwykle kilka podstawowych elementów. Jest to zjawisko wielowarstwowe, a wartości, normy, przekonania i symbole, które leżą u podstaw zachowań kręgów związanych ze szkołą, nie zawsze pokrywają się z wartościami i normami deklarowanymi w oficjalnych dokumentach i deklaracjach szkoły. Szkoła katolicka całą ludzką kulturę porządkuje ostatecznie zgodnie $\mathrm{z}$ orędziem zbawienia, tak aby poznanie, które wychowankowie stopniowo zdobywają odnośnie do świata, życia i człowieka, było oświetlone wiarą. Szkoła salezjańska jest osadzona w posłannictwie Kościoła. Dokumenty Towarzystwa Salezjańskiego podkreślaja, że szkoła salezjańska powstała w Oratorium na Valdocco (Turyn), aby odpowiedzieć na konkretne potrzeby młodzieży i włączyć się w powszechny program wychowania i ewangelizacji młodzieży, szczególnie najuboższej. Misja szkoły salezjańskiej: wychowywać „uczciwych obywateli i dobrych chrześcijan”, jest podstawowym narzędziem kształtowania jej kulturowej tożsamości, określa bowiem podstawowe cele, wartości i zasady działania, wyrażone w specyficzny sposób, które orientują codzienną jej aktywność.

Słowa kluczowe: szkoła; kultura szkoły; szkoła katolicka; system prewencyjny; wychowanie.

\section{Bibliografia}

Adrjan, Beata. Kultura szkoły. W poszukiwaniu nieuchwytnego. Kraków: Impuls, 2011. Bosco, Teresio. Zlote myśli Księdza Bosko. Warszawa: Wydawnictwo Salezjańskie, 2002.

Bronk, Andrzej. „Kultura”. W: Leksykon filozofii klasycznej, red. Józef Herbut, 332 -335. Lublin: Towarzystwo Naukowe KUL, 1997.

Buhler, Patricia. Zarzadzanie. Gliwice: Wydawnictwo Helion, 2002.

Chavez, Villanueva Pascual. „Salezjańska służba młodzieży na polu edukacji”. W: Ks. Pascual Chávez Villanueva SDB, generat Towarzystwa św. Franciszka Sa- 
lezego: doktor honoris causa Katolickiego Uniwersytetu Lubelskiego Jana Pawta II, 63-95. Lublin: KUL, 2011.

Cian, Luciano. Wychowanie w duchu Księdza Bosko. Warszawa: Wydawnictwo Salezjańskie, 1990.

Cian, Luciano. System zapobiegawczy św. Jana Bosko i jego charakterystyka. Warszawa: Wydawnictwo Salezjańskie, 2001.

De Pieri, Severino. Ukierunkowanie w wychowaniu i towarzyszenie powołaniu. Warszawa: Wydawnictwo Salezjańskie, 2002.

Gatti, Guido. „Tradycja wychowawcza ks. Bosko dzisiaj: konieczność wychowawcy". W: Współczesny wychowawca w stylu księdza Bosko, red. Józef Wilk, 67-81. Lublin: Poligrafia Inspektoratu Towarzystwa Salezjańskiego, 1998.

Gołębniak, Bogusława Dorota. „Szkoła wspomagająca rozwój”. W: Pedagogika. Podręcznik akademicki, red. Zbigniew Kwieciński, Bogusław Śliwerski, 98-122. Warszawa: Wydawnictwo Naukowe PWN. 2003.

Jan Paweł II. Iuvenum patris. List Ojca Świętego Jana Pawła II do księdza Egidio Viganó Przełożonego Generalnego Towarzystwa św. Franciszka Salezego w setna rocznice śmierci św. Jana Bosko. Tipografia Poliglotta Vaticana, 1988.

Jan Paweł II. ,Zadania szkoły. List na Światowy Dzień Modlitw o Powołania Kapłańskie i Zakonne, Watykan, 2 lutego 1989”. L 'Osservatore Romano 1-2 (1989): 25.

Jan Paweł II. List do rodzin. Wrocław: Wydawnictwo Wrocławskiej Księgarni Archidiecezjalnej, 1994.

Jan Paweł II. Encyklika Fides et ratio. Poznań: Pallottinum, 1998.

Jaroszyński, Piotr. „Edukacja na rozdrożu cywilizacji”. W: Filozofia i edukacja, red. Piotr Jaroszyński, Paweł Tarasiewicz, Imelda Chłodna, 13-21. Lublin: Fundacja „Lubelska Szkoła Filozofii Chrześcijańskiej”, 2005.

Kodeks Prawa Kanonicznego. Poznań: Pallottinum, 1984.

Kongregacja ds. Wychowania Katolickiego. „Świecki katolik świadkiem wiary w szkole". W: Paideia chrześcijańska. Cz. 1. Wychowanie człowieka w nauczaniu Kościoła, 137-193. Warszawa: Ośrodek Działalności Kulturalnej i Edukacji Narodowej, Stowarzyszenie PAX, 1982.

Kongregacja ds. Wychowania Katolickiego. „Szkoła katolicka u progu trzeciego tysiąclecia". W: Szkoła miejscem ksztaltowania postawy patriotycznej, 105-131. Częstochowa: Biblioteka „Niedzieli”, 1997.

Kongregacja Nauczania Katolickiego. „Szkoła katolicka”. W: Paideia chrześcijańska. Cz. 1. Wychowanie człowieka w nauczaniu Kościoła, 89-136. Warszawa: Ośrodek Działalności Kulturalnej i Edukacji Narodowej, Stowarzyszenie PAX, 1977.

Kongregacja Wychowania Katolickiego. Osoby konsekrowane i ich misja w szkole. Refleksje i wskazania. Poznań: Pallottinum, 2003. 
Konstytucje Towarzystwa św. Franciszka Salezego. Rzym: S.G.S. Istituto Pio XI, 1986.

Kostera, Monika. Zarzadzanie personelem. Warszawa: Polskie Wydawnictwo Ekonomiczne, 1994.

Maryniarczyk, Andrzej. „Religia w posłudze wychowawcy: anachronizm czy niezbywalny wymóg?". W: Współczesny wychowawca w stylu księdza Bosko, red. Józef Wilk, 105-121. Lublin: Poligrafia Inspektoratu Towarzystwa Salezjańskiego, 1998.

Misiaszek, Kazimierz. „Pedagogia salezjanów (Towarzystwa Św. Franciszka Salezego)". W: Pedagogie katolickich zgromadzeń zakonnych. Historia i wspótczesność, t. 1, red. Janina Kostkiewicz, 229-269. Kraków: Wydawnictwo Impuls, 2012.

Nalaskowski, Aleksander. Przestrzenie i miejsca szkoły. Kraków: Oficyna Wydawnicza „Impuls”, 2002.

Nowak, Marian. „Laudacja”. W: Ks. Pascual Chávez Villanueva SDB, generat Towarzystwa św. Franciszka Salezego: doktor honoris causa Katolickiego Uniwersytetu Lubelskiego Jana Pawła II, 41-62. Lublin: KUL, 2011.

Okulicz-Kozaryn, Katarzyna. Klimat i kultura szkoły a zdrowie psychiczne uczniów i nauczycieli. 2015. https://www.ore.edu.pl/index.php?...i-kultura...i...

Olbrycht, Katarzyna. „Aksjologia szkoły katolickiej”. Ethos 75 (2006): 91-98.

Ostaszewski, Krzysztof. „Kultura szkoły a zachowania ryzykowne uczniów”. Edukacja 1 (2014): 14-24.

Pedagogika. Leksykon PWN, red. Bogusław Milerski, Bogusław Śliwerski. Warszawa: Wydawnictwo Naukowe PWN, 2000.

Salezjańskie duszpasterstwo młodzieżowe. Podstawowe punkty i odniesienia. Kraków: Salezjańskie Centrum Wychowania i Duszpasterstwa, 1999.

Smolińska-Theiss, Barbara, Wiesław Theiss. „Asystencja i dialog pedagogiczny”. W: Jestem wychowawca. Model pracy z uczniem i klasq szkolnq wedtug systemu prewencyjnego Jana Bosko, red. Kazimierz Franczak, 43-53. Warszawa: Salezjański Instytut Wychowania Chrześcijańskiego, 2004.

Sobór Watykański II. „Deklaracja o wychowaniu chrześcijańskim Gravissimum educationis". W: Sobór Watykański II. Konstytucje, Dekrety, Deklaracje. Poznań: Pallottinum, 1986.

Szczupaczyński, Jerzy. Edukacja a zarzqdzanie. Pułtusk: Wyższa Szkoła Humanistyczna im. Aleksandra Gieysztora, 2004.

Wereszczyńska, Katarzyna. „Wychowanie szkolne - między socjalizacją a indywidualizacją". W: Wychowanie w szkole: od bezradności ku możliwościom, red. Radosław Chałupniak, Tomasz Michalewski, Ewa Smak, 109-118. Opole: Redakcja Wydawnictw Wydziału Teologicznego UO, 2014. 